\title{
Reading the Body
}




\section{Regendering the Past}

Cheryl Claassen, Series Editor

A complete list of books in the series

is available from the publisher. 


\section{Reading the Body}

Representations and Remains in the Archaeological Record

Edited by Alison E. Rautman

\section{$\overline{\text { PENN }}$}

University of Pennsylvania Press

Philadelphia 
Copyright $(2000$ University of Pennsylvania Press

All rights reserved

Printed in the United States of America on acid-free paper

$\begin{array}{llllllllll}10 & 9 & 8 & 7 & 6 & 5 & 4 & 3 & 2 & 1\end{array}$

Published by

University of Pennsylvania Press

Philadelphia, Pennsylvania 19104-401 1

Library of Congress Cataloging-in-Publication Data

Reading the body : representations and remains in the archaeological record / edited by Alison E. Rautman.

p. cm. - (Regendering the past)

Includes bibliographical references and index.

ISBN 0-8122-3521-5 (acid-free paper). -

ISBN 0-8122-1709-8 (pbk, : acid-free paper)

1. Social archaeology. 2. Women, Prehistoric. 3. Sex roleHistory. 4. Sex differences-History. 5. Human remains

(Archaeology). 6. Body, Human - Symbolic aspects. I. Rautman, Alison E. II. Series.

CC72.4.R444 1999

$930.1^{\prime} 028^{\prime} 5-\mathrm{dc} 21$

99-33513 